\title{
Hydrolysis and mineralization of chitin in the Delaware Estuary
}

\author{
David L. Kirchman*, Jacques White** \\ College of Marine Studies, University of Delaware, Lewes, Delaware 19958, USA
}

\begin{abstract}
We examined various aspects of chitin degradation in order to estimate degradation rates and the contribution of chitin to supporting bacterial growth in the Delaware estuary. Hydrolysis of the chitin analog, methylumbelliferyl-N, $\mathrm{N}^{\prime}$-diacetyl-chitobioside (MUF-diNAG), and mineralization of ${ }^{14} \mathrm{C}$ chitin varied in a complex pattern in the estuary and correlated only weakly at best with various indices of chitin production. Rates of MUF-diNAG hydrolysis and ${ }^{14} \mathrm{C}$-chitin degradation were within an order of magnitude of each other, with hydrolysis rates usually exceeding chitin mineralization. Consistent with hydrolysis being greater than mineralization, we found substantial release of ${ }^{14} \mathrm{C}$-labeled dissolved organic matter (DOM) during degradation of the ${ }^{14} \mathrm{C}$-chitin; DOM release was roughly equal to respiration of ${ }^{i 4} \mathrm{C}$-chitin. This DOM release could support growth of bacteria not attached or otherwise associated with the chitin, but rates of DOM release and direct chitin degradation seem low relative to bacterial production. During 2 cruises in July and October, chitin appeared to support $5 \%$ or less of bacterial production, whereas during one cruise in September the percentage was about 30\%. Estimates of chitin inputs into marine systems indicate that on the order of $10 \%$ of bacterial production could be supported by chitin. Although it appears low, few individual biochemicals are likely to support much more bacterial growth than chitin, with the possible exception of protein and amino acids.
\end{abstract}

KEY WORDS: Chitin $\cdot$ DOC $\cdot$ DOM $\cdot$ Heterotrophic bacteria $\cdot$ Detritus

\section{INTRODUCTION}

The general mechanism by which bacteria degrade organic detritus in pelagic environments is understood. Bacteria attach to detritus, if only briefly, in order to hydrolyze detrital biopolymers via cell-bound ectoenzymes or exoenzymes released into restricted microniches afforded by the detritus. The low molecular weight (LMW) byproducts are then assimilated by particle-bound bacteria, or are released into the surrounding water if rates of biopolymer hydrolysis exceed uptake by the particle-bound bacteria. Although the general outline of detritus degradation is understood, we need more information about overall rates of detritus degradation, the relative contribution of detrital

\footnotetext{
•E-mail: kirchman@udel.edu

- Present address: People for Puget Sound, Seattle, Washington 98101, USA
}

carbon to supporting bacterial growth, and the relationships among various aspects of particulate organic matter (POM) degradation, specifically hydrolysis of macromolecules comprising detritus and subsequent uptake of LMW byproducts by bacteria.

There is some evidence indicating that hydrolysis exceeds uptake of LMW byproducts, at least over short time periods (<1 d). Smith et al. (1992) observed a large release of dissolved combined amino acids (DCAA) from larvacean houses, diatom flocs and fecal pellet marine snow aggregates in the California Bight. This release was calculated to be 50 to $98 \%$ of total degradation, where the 'total' was defined as DCAA release plus bacterial carbon demand, as estimated from bacterial production. Release of DCAA and presumably of other dissolved organic matter (DOM) implies that hydrolysis rates of detrital biopolymers exceed uptake by particle-bound bacteria. It is not clear if this uncoupling between hydrolysis and uptake is common and occurs with other types of particulate detritus. 
The few studies examining hydrolysis of dissolved biopolymers have come to different conclusions about the relationship between hydrolysis and uptake. Keil \& Kirchman (1993), for example, found that about $30 \%$ of utilized dissolved protein was released as LMW byproducts in the Delaware Bay Estuary, whereas Rosenstock \& Simon (1993) observed little if any free amino acid release during protein degradation in Lake Constance. Although the methodological details of the 2 studies differed, both used radiolabeled substrates to examine protein utilization, an approach not entirely suited for examining hydrolysis per se, because it is difficult to separate hydrolysis from uptake of the radiolabeled byproducts. Hydrolysis is usually measured using fluorogenic analogs because they are sensitive and easy to use and because uptake of byproducts does not affect estimates of hydrolysis rates. However, these analogs may not trace adequately all aspects of biopolymer degradation. Even when the analog mimics faithfully the characteristic linkage of a biopolymer, hydrolysis of a LMW analog may not correlate with rates at all steps in the degradation of a high molecular weight polymer. Although these potential problems are well known, the relationship between fluorogenic analog hydrolysis and degradation of an actual biopolymer has not been examined.

Chitin is an important compound for examining the relationship between hydrolysis and degradation because inputs of detrital chitin into the oceans may be very high. Chitin is synthesized by several marine organisms (for general reviews, see Gooday 1990, Mulisch 1993), as extracellular material from selected algae (e.g. Blackwell et al. 1967, Chrétiennot-Dinet \& Giraud-Guille 1997), cell walls of some chlorophytes (Mulisch 1993), exoskeletons, including molts from copepods and marine invertebrate larvae (Gooday 1990), and the peritrophic membrane of fecal pellets excreted by copepods (Yoshikoshi \& Kô 1988). In spite of being recognized as the second most abundant biopolymer in nature (Gooday 1990), surprisingly few ecological studies have examined chitin degradation (Boyer 1986, 1994, Herwig et al. 1988), although several studies have used fluorogenic analogs to examine chitinase activity. Chitin is generally thought to be degraded easily, but recent studies indicate that some forms of chitin may be somewhat refractory to bacterial attack. McCarthy et al. (1997) suggested that byproducts from chitin degradation may contribute to the dissolved organic nitrogen pool implying that some soluble chitin components are degraded slowly. Also, chitin has been found preserved in fossils (e.g. Stankiewicz et al. 1997).

There is some evidence that DOM is released during chitin degradation, i.e. that hydrolysis exceeds uptake and degradation of LMW byproducts. Boyer (1994) found 12 to $21 \%$ of added ${ }^{14} \mathrm{C}$-chitin was released into the dissolved pool in sediment samples, but he did not observe any DOM production in water column samples. Chitin appears to be degraded very rapidly, with 20 to $30 \%$ removed $\mathrm{d}^{-1}$ in the York River estuary (Boyer 1994), although other studies have found slower rates (e.g. Hillman et al. 1989). The contribution of chitin to supporting bacterial growth, however, is unknown.

Here we examine chitinase activity and the degradation of chitin in the Delaware estuary. We compared hydrolysis of the fluorogenic analog of chitin, methylumbelliferyl-N,N'-diacetyl-chitobioside (MUF-diNAG), with rates of mineralization and solubilization (DOM production) from ${ }^{14} \mathrm{C}$-chitin. We found substantial DOM production during chitin degradation, consistent with data showing chitin hydrolysis generally exceeding chitin mineralization. Rates of chitin degradation, however, were low compared to bacterial production.

\section{METHODS AND MATERIALS}

The experiments discussed here were conducted with surface water samples collected along transects of the Delaware Bay in 1995. Hoch \& Kirchman (1993) give a map of the transects that ranged from the Delaware River (freshwater) to coastal waters. Chlorophyll concentrations were measured from the fluorescence in acetone-extractions of particulate material collected on GF/F filters. In October, chlorophyll was estimated from in vivo fluorescence and from regression analysis of chlorophyll concentrations versus in vivo fluorescence measured during other cruises weeks before and after the October cruise. Incubations for chitinase activity and chitin degradation (see below) were conducted at surface seawater temperatures in the dark.

Hydrolysis of a chitin analog. Chitinase activity was estimated from the hydrolysis of the chitin analog MUF-diNAG (Sigma). Hydrolysis of the chitin-like bond releases a fluorescent byproduct, methylumbellerone (MUF). In July and September, MUFdiNAG was added at 2 concentrations $150 \mathrm{nM}$ or $50 \mu \mathrm{M}$ ) and after a ca $10 \mathrm{~h}$ incubation, the reaction was killed by the addition of glycine buffer ( $\mathrm{pH} \mathrm{10.5;}$ Montgomery \& Kirchman 1993) which also enhances the fluorescence. Fluorescence was measured by a Hoeffer DNA fluorometer. Fluorescence of MUF at various concentrations was determined to estimate moles of MUF released during MUF-diNAG hydrolysis. In September, MUF-diNAG hydrolysis was examined at several MUF-diNAG concentrations (see 'Results'). 
Synthesis and characterization of ${ }^{14} \mathrm{C}$-chitin. We examined the production of ${ }^{14} \mathrm{C}$-labeled dissolved organic carbon $\left(\mathrm{DO}^{14} \mathrm{C}\right)$ and respiration of ${ }^{14} \mathrm{CO}_{2}$ during degradation of ${ }^{14} \mathrm{C}$-chitin. Since it is not commercially available, it was necessary to synthesize ${ }^{14} \mathrm{C}$ chitin by feeding the fungus Paeosphaeria spartinicola $\mathrm{N}$-acetyl- ${ }^{14} \mathrm{C}$-glucosamine (Amersham). This fungus, originally isolated from the salt marsh around Sapelo Island, Georgia, is thought to be one of the major decomposers of standing-dead marsh grass, specifically Spartina alterniflora (Newell 1993), although we used it mainly because fungi have chitinous cell walls.

The fungus was inoculated into a media containing

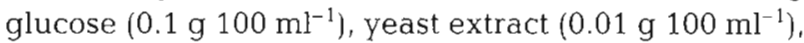
and $10 \mu \mathrm{Ci}$ of $\mathrm{N}$-acetyl- $\left[1-{ }^{14} \mathrm{C}\right]$-glucosamine in $15 \mathrm{PSU}$ seawater ( $20 \mathrm{ml}$ total). After growth for $5 \mathrm{~d}$, the fungus was harvested by centrifugation and the pellet rinsed twice with dionized water (Milli Q-water); all centrifugations mentioned here were at $13000 \mathrm{rpm}(15000 \times \mathrm{g})$ in a microcentrifuge. Epifluorescence microscopy revealed no contaminating bacteria. The following procedure to isolate ${ }^{14} \mathrm{C}$-chitin was based on Roff et al. (1994). After sonicating the resuspended fungal pellet briefly to break up the clumps, SDS was added to $4 \%$ final concentration and incubated at $90^{\circ} \mathrm{C}$ for $2 \mathrm{~h}$. After cooling, the mixture was centrifuged and the resulting pellet resuspended in a Tris-EDTA buffer ( $\mathrm{pH} 7,5)$; the pellet was again sonicated briefly to break up the clumps. Protease $\mathrm{K}$ was added to a final concentration of $1 \mathrm{mg} \mathrm{ml}^{-1}$ and incubated overnight at $37^{\circ} \mathrm{C}$. The mixture was again centrifuged and the pellet was resuspended in SDS to remove protease bound to the partially-purified chitin. The mixture was again centrifuged and the pellet washed 3 times with Milli-Q water. The pellet was then resuspended and washed twice in chloroform plus methanol (1:1) after which the pellet was dried. The dried pellet was resuspended in sterile deionized water and sonicated to disperse the pellet. The average specific activity of the ${ }^{14} \mathrm{C}$-chitin

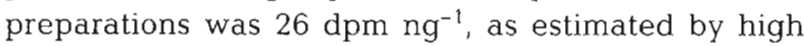
performance liquid chromatography (HPLC).

The specificity of the labeling and purity of the ${ }^{14} \mathrm{C}$ chitin preparations were examined by HPLC. Subsamples from various radiolabeled chitin batches were hydrolyzed in $\mathrm{HCl}$ ( 1 part aqueous sample:9 parts concentrated $\mathrm{HCl}$ ) for $10 \mathrm{~h}$ at $80^{\circ} \mathrm{C}$ (Rupley 1964). Our preliminary analysis indicates that this procedure gives equal or higher recovery of glucosamine from chitin than the following procedures: $6 \mathrm{~N} \mathrm{HCl}$ for $20 \mathrm{~h}$ at $110^{\circ} \mathrm{C}$ (Smucker \& Dawson 1986), $3 \mathrm{~N} \mathrm{HCl}$ for $4 \mathrm{~h}$ at $100^{\circ} \mathrm{C}$, and the $\mathrm{H}_{2} \mathrm{SO}_{4}$ method often used for polysaccharides (Pakulski \& Benner 1992). Subsamples from the hydrolyzed chitin were diluted 1:500 with deionized water and analyzed by ion exchange HPLC with pulse amperometric detection (Borch \& Kirchman
1997). Aliquots $(0.5 \mathrm{ml})$ from the HPLC were collected with a fraction collector and radioassayed.

In order to measure incorporation of chitin carbon into bacterial biomass, it is necessary to examine uptake of 'soluble chitin', i.e. chitin oligomers that pass through $0.2 \mu \mathrm{m}$ filters. Incorporation of carbon from particulate ${ }^{14} \mathrm{C}$-chitin carnot be examined because ${ }^{14} \mathrm{C}$ in bacterial biomass cannot be distinguished from the original particulate ${ }^{14} \mathrm{C}$-chitin. To synthesize ${ }^{14} \mathrm{C}$-chitin oligomers, we did a partial acid hydrolysis of ${ }^{14} \mathrm{C}$-chitin obtained as described above. Domard \& Cartier (1989) found that hydrolysis of chitosan with $12 \mathrm{M} \mathrm{HCl}$ for $30 \mathrm{~min}$ at $70^{\circ} \mathrm{C}$ resulted in chitin oligomers, $>90 \%$ of which were larger than dimers of glucosamine; the dimer is thought to be the largest chitin byproduct that can be transported by bacteria (e.g. Bassler et al. 1991). However, we found that hydrolysis of chitin in $3 \mathrm{M} \mathrm{HCl}$ for 5 min at $70^{\circ} \mathrm{C}$ was necessary; based on HPLC analysis, this hydrolysis condition gave $<5 \%$ LMW products (e.g. glucosamine and dimers of glucosamine and $\mathrm{N}$-acetylglucosamine) while resulting in usable amounts of soluble, high molecular weight ${ }^{14} \mathrm{C}$-chitin oligomers. After hydrolysis, the chitin suspension was placed on ice, neutralized by slowing adding solid $\mathrm{NaHCO}_{3}$ until the bubbling stopped, and then filtered through a $0.22 \mu \mathrm{m}$ microfuge filter (Micropure, Amicon). The soluble chitin oligomers $(<0.22 \mu \mathrm{m})$ were used in experiments.

Uptake and respiration of ${ }^{14} \mathrm{C}$-chitin oligomers in Delaware coastal waters were examined in an experiment in December 1998. The ${ }^{14} \mathrm{C}$-chitin oligomers were added to 3 live and 2 killed samples and were incubated for $24 \mathrm{~h}$ at $19^{\circ} \mathrm{C}\left(7^{\circ}\right.$ above in situ temperature). After incubation, the water was acidified and ${ }^{14} \mathrm{CO}_{2}$ collected as described below. After respiration was measured, radioactivity incorporated into microbes was collected on $0.2 \mu \mathrm{m}$ polycarbonate filters (Poretics) and rinsed twice with about $3 \mathrm{ml}$ filtered seawater. We define \% incorporation efficiency as: incorporation into biomass/(respiration + incorporation) $x$ 100.

Degradation of ${ }^{14} \mathrm{C}$-chitin. After storage at $-20^{\circ} \mathrm{C}$, ${ }^{14} \mathrm{C}$-chitin preparations were thawed and sonicated to break up the clumps and to obtain a uniform suspension of particles. Subsamples of these suspensions were added to surface seawater (ca $0.5 \mathrm{~m}$ ) from various locations in the Delaware estuary (see 'Results') and incubated for about $12 \mathrm{~h}$ at in situ temperatures in the dark. The final concentration of added ${ }^{14} \mathrm{C}$-chitin was $489 \mu \mathrm{g}^{-1}$ in July and $293 \mu \mathrm{g} \mathrm{I}^{-1}$ in September and October. Controls killed with formaldehyde were run at the same time. At the end of the incubation, the undegraded chitin particles were removed by filtration $(0.45 \mu \mathrm{m})$ and the ${ }^{14} \mathrm{CO}_{2}$ was radioassayed by acidifying the sample and collecting the evolved ${ }^{14} \mathrm{CO}_{2}$ in a 
base trap (Crawford \& Crawford 1976). The acid stable radioactivity remaining in solution, i.e. dissolved organic carbon (DOC), was also radioassayed.

Bacterial production was measured using the dual label approach with ${ }^{14} \mathrm{C}$-leucine (Leu) and ${ }^{3} \mathrm{H}$ thymidine (TdR) (Chin-Leo \& Kirchman 1988). Incorporation rates (nM $\mathrm{h}^{-1}$ ) were converted to carbon units ( $\mu \mathrm{g} \mathrm{C}^{-1} \mathrm{~d}^{-1}$ ) using the conversion factor $1.1 \times 10^{18}$ and $6.5 \times 10^{16}$ cell $\mathrm{mol}^{-1}$ for $\mathrm{TdR}$ and Leu, respectively. These factors were measured in the Delaware estuary during empirical conversion factor experiments conducted in 1986-1989 (Hoch \& Kirchman 1993). The more commonly used factors are higher by almost 2-fold than these factors, but if we would use the higher factors, our conclusions would not change. Cell mass was assumed to be $20 \mathrm{fg} \mathrm{C}$ cell $^{-1}$ (Lee \& Fuhrman 1987).
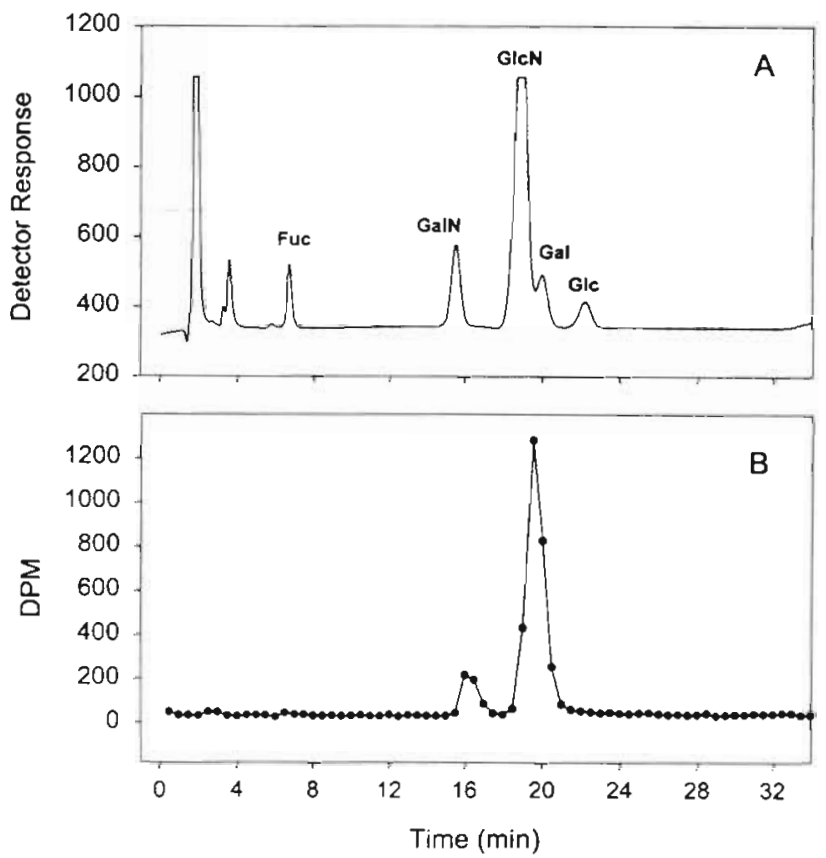

Fig. 1. Example of a chromatogram from HPLC analysis of radiolabeled chitin preparation. Radiolabeled chitin was subjected to acid hydrolysis and the resulting monomers were analyzed by HPLC. The top panel is the response from the PAD detector and the bottom panel gives the radioactivity $(\mathrm{dpm})$ recovered in each fraction. The 2 peaks in the collected radioactivity are offset from the GalN and GicN peaks in the detector response because of the delay between the detector and fraction collection. Fuc $=$ fucose, added as an internal standard GalN = galactosamine; GlcN = glucosamine, the expected monomer resulting from acid hydrolysis of chitin; $\mathrm{Gal}=$ galactose, and $\mathrm{Glc}=$ glucose

\section{RESULTS}

\section{Characterization of ${ }^{14} \mathrm{C}$-chitin and MUF-diNAG hydrolysis}

The ${ }^{14} \mathrm{C}$-chitin used to examine chitin degradation during this study was characterized by HPLC analysis of the monomers released by acid hydrolysis. Most of the presumed chitin could be recovered as glucosamine following acid hydrolysis (average of $68 \%$ ), and only small amounts of galactosamine $(15 \%$ of total), galactose $(9 \%)$, and glucose $(7 \%)$ were measured in the hydrolysate (Table 1); Fig. 1 is a typical chromatogram and the results from 3 hydrolyses are given in Table 1. Glucosamine is the expected byproduct from acid hydrolysis of chitin as $\mathrm{N}$-acetylglucosamine is deacetylated under these hydrolysis conditions. There was no evidence of protein associated with this chitin as amino acids were not detected, indicating that the protease clean-up of the chitin was effective. Nearly all radioactivity (86\%) coeluted with

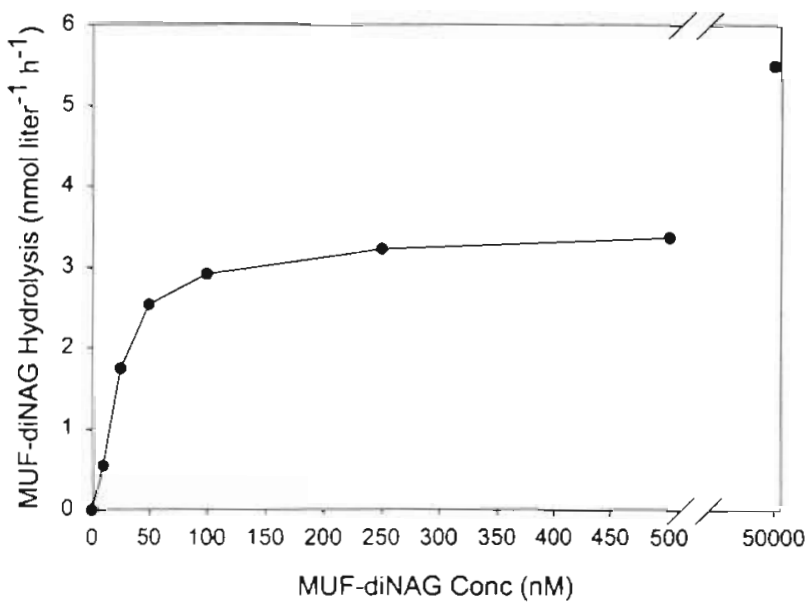

Fig. 2. Hydrolysis of MUF-diNAG at various MUF-diNAG concentrations 
glucosamine and the rest of the radioactivity $(14 \%)$ coeluted with galactosamine (Table 1). Although we do not understand the presence of galactosamine, and the hydrolysis procedure could be improved loverall recovery of radioactivity in HPLC elutions was $78 \pm$ $15 \%$, these results indicate that the ${ }^{14} \mathrm{C}$-chitin was sufficiently pure and radiolabeled correctly for the purposes of this study.

An experiment in September determined that MUFdiNAG hydrolysis was highest at $50 \mu \mathrm{M}$ (Fig. 2). During July and September, hydrolysis rates were measured at 2 concentrations ( $50 \mu \mathrm{M}$ and $50 \mathrm{nM}$ ) along the transect. The ratio of $50 \mu \mathrm{M}$ rate to the $50 \mathrm{nM}$ rate was $14.7 \pm 6.6(\mathrm{SE} ; \mathrm{n}=23)$. Hydrolysis rates of MUF-diNAG at $50 \mu \mathrm{M}$ and $50 \mathrm{nM}$ were not correlated $(\mathrm{r}=0.29 ; \mathrm{n}=$ 23). For simplicity, we discuss below only rates of MUF-diNAG hydrolysis determined by hydrolysis of $50 \mu \mathrm{M}$ MUF-diNAG.
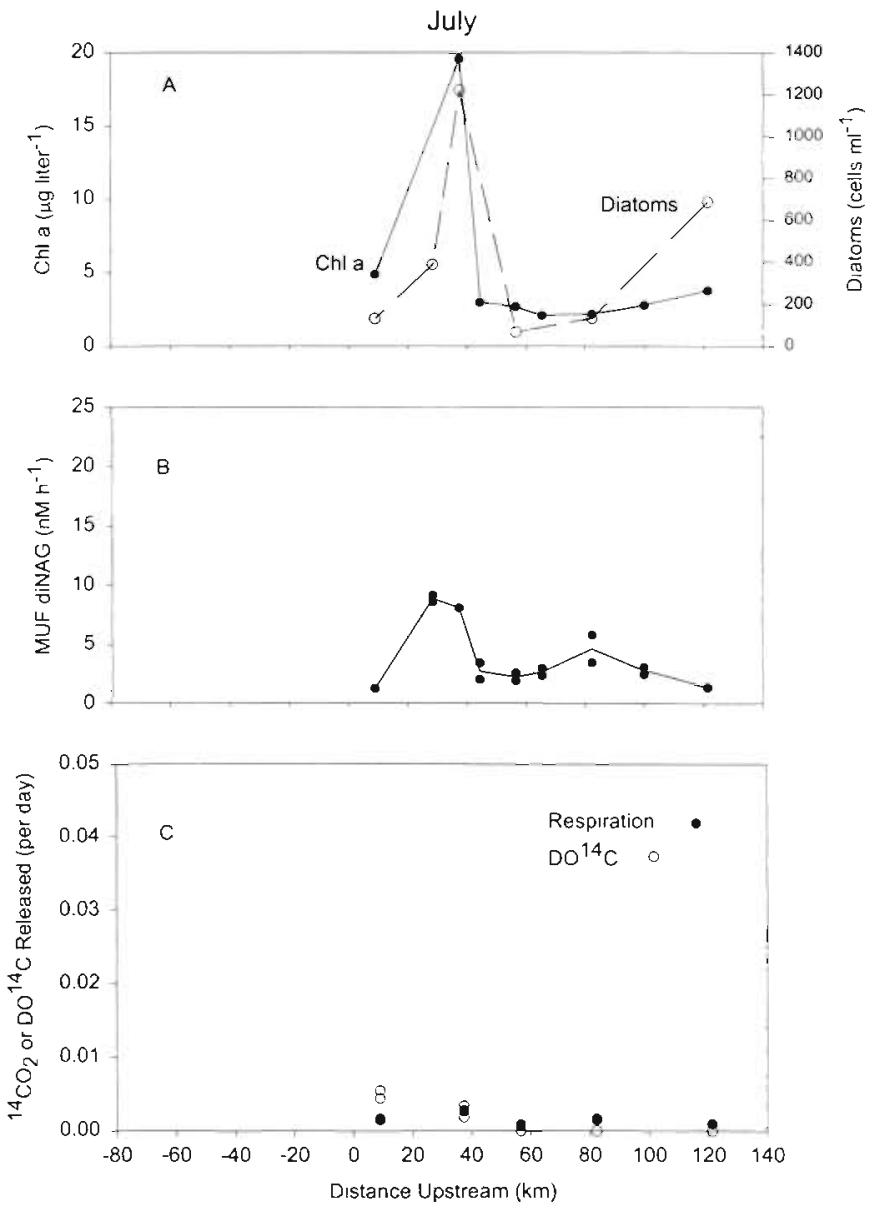

Fig. 3. Possible chitin sources and chitin degradation in the Delaware Estuary during July 1995. The zero for 'Distance upstream' is set at the mouth of the estuary. (A) Chlorophyll a and diatom abundance; (B) MUF-diNAG hydrolysis rate; and (C) mineralization to ${ }^{14} \mathrm{CO}_{2}$ or release of $\mathrm{DO}^{14} \mathrm{C}$ from ${ }^{14} \mathrm{C}$ chitin

\section{Spatial and temporary variation in chitin degradation and chitinase activity}

We compared chitin degradation with ${ }^{14} \mathrm{C}$-chitin and chitinase activity (MUF-diNAG hydrolysis) with indices of chitin sources (chlorophyll and numbers of diatoms and zooplankton) during 3 cruises in the Delaware Estuary. The dominant feature of these transects is the chlorophyll maximum at about $30 \mathrm{~km}$ upstream from the mouth of the estuary. This maximum was sharpest and highest in July (Fig. 3A) and then decreased in September (Fig. 4A) and October (Fig. 5A); by October chlorophyll varied less (10-fold) than observed in the other 2 months (20-fold).

Maxima in chitinase activity coincided with the chlorophyll maximum in July (Fig. 3B) and September (Fig. 4B), but there is little variation in MUF-diNAG hydrolysis in October along the estuarine transect
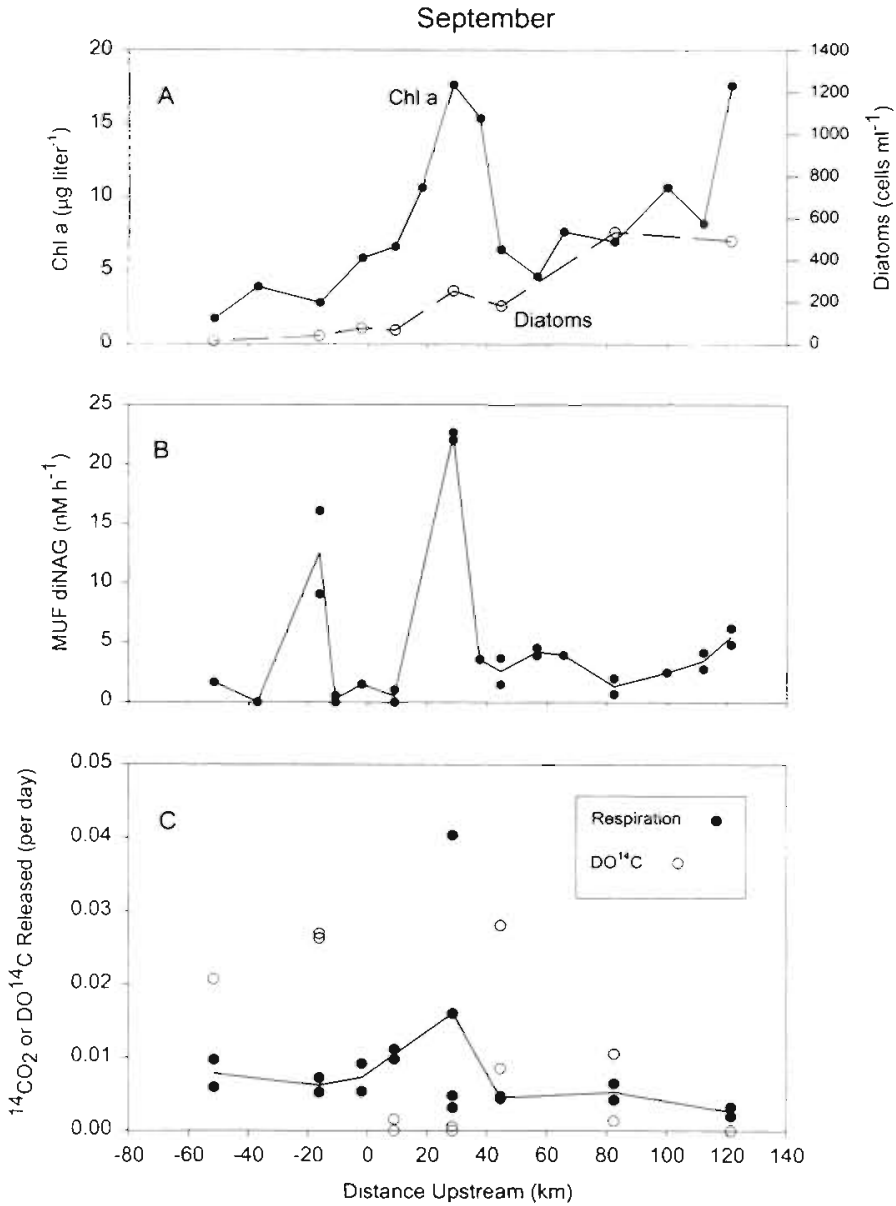

Fig. 4. Possible chitin sources and chitin degradation in the Delaware Estuary during September 1995. The zero for 'Distance upstream' is set at the mouth of the estuary. (A) Chlorophyll $a$ and diatom abundance; (B) MUF-diNAG hydrolysis rate; and $(\mathrm{C})$ mineralization to ${ }^{14} \mathrm{CO}_{2}$ or release of $\mathrm{DO}^{14} \mathrm{C}$ from ${ }^{14} \mathrm{C}$-chitin 

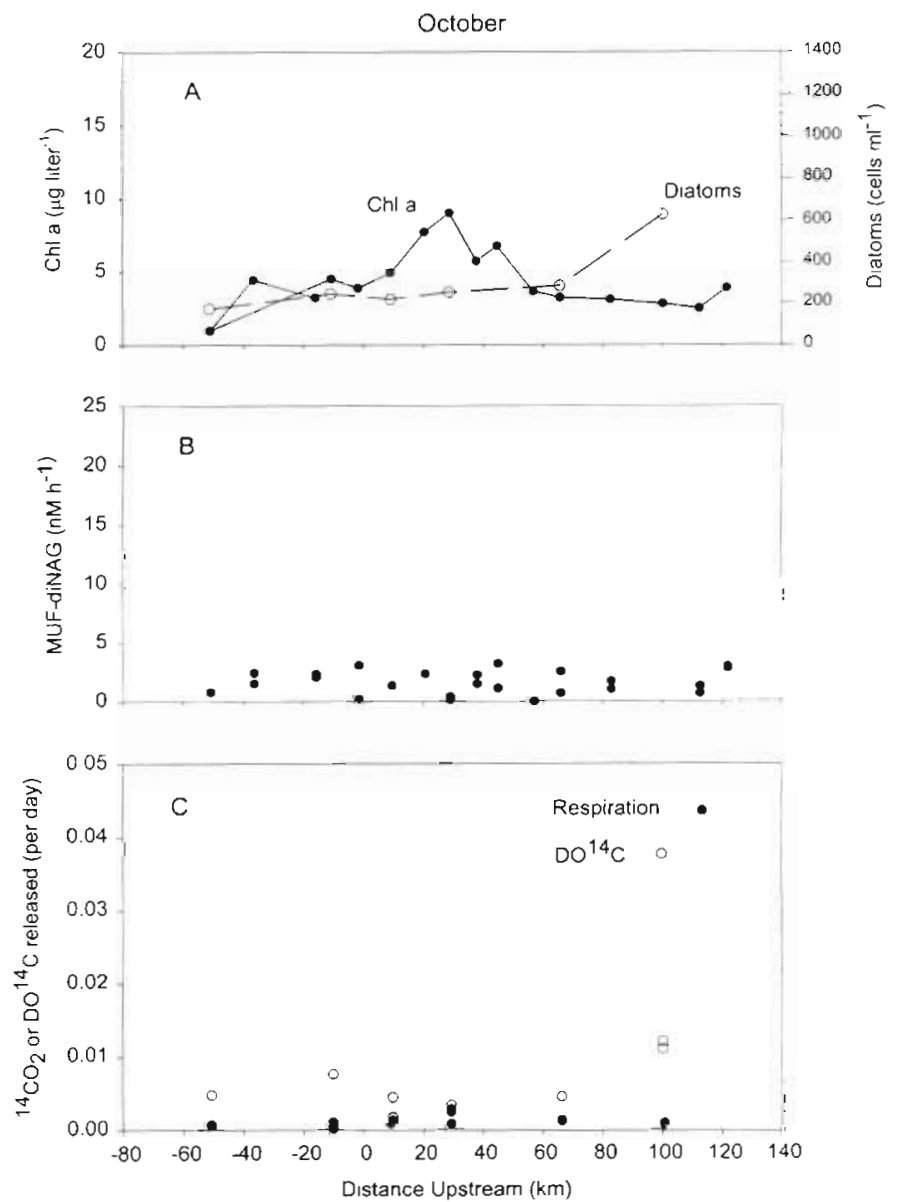

Fig. 5. Possible chitin sources and chitin degradation in the Delaware Estuary during October 1995. The zero for 'Distance upstream' is set at the mouth of the estuary. (A) Chlorophyll $a$ and diatom abundance; (B) MUF-diNAG hydrolysis rate; and $(C)$ mineralization to ${ }^{14} \mathrm{CO}_{2}$ or release of $\mathrm{DO}^{14} \mathrm{C}$ from ${ }^{14} \mathrm{C}$-chitin

(Fig. 5B). In September, there was a 1 station peak in MUF-diNAG hydrolysis at $-20 \mathrm{~km}$ which did not coincide with any measure of potential chitin sources. There was no significant variation in rates of ${ }^{14} \mathrm{C}$-chitin degradation along the estuary (Figs, 3C, 4C \& 5C).

The various indices of chitin sources indicate that the input of chitin is likely to vary greatly and in a complex fashion. The maximum abundance of diatoms (some of which produce chitin; see 'Introduction') did coincide with chlorophyll maximum at $30 \mathrm{~km}$ in July (Fig. 3A), but there was no significant correlation between chlorophyll and diatom abundance $(r=-0.37 ; n=20)$ when all data were considered together. The limited data indicated that zooplankton were more abundant in the lower estuary and offshore than in the upper estuary ( $>40 \mathrm{~km}$; Table 2 ), whereas diatoms were less abundant in the lower estuary and offshore, especially in September (Fig. 4A) and October (Fig. 4B). Differ- ences in the distribution of possible chitin sources perhaps lead to complex (Fig. 4B) or no variation (Fig. 5B) in chitinase activity.

\section{Mineralization and solubilization of ${ }^{14} \mathrm{C}$-chitin}

Given the lack of clear and significant variation along the transect (Figs. 3C, 4C \& 5C), degradation rates of ${ }^{14} \mathrm{C}$-chitin were averaged over each cruise (month) and summarized in Table 3 . In order to express in $\mathrm{C}$ units, we assumed that the specific activity of the degraded chitin was that of the added chitin. This assumption seems reasonable given that the addition of chitin was large relative to expected concentrations (see 'Discussion').

A substantial amount of $\mathrm{DO}^{14} \mathrm{C}$ was apparently released during degradation of ${ }^{14} \mathrm{C}$-chitin over $12 \mathrm{~h}$ incubations. Roughly $50 \%$ of the degraded ${ }^{14} \mathrm{C}$ was released as $\mathrm{DO}^{14} \mathrm{C}$ and the other $50 \%$ as ${ }^{14} \mathrm{CO}_{2}$ (Table 3$)$. There is much variability $( \pm 40 \%)$ in these percentages, however (Table 3). In addition to Figs. 3 to 5 , one indication of the variability is that the ratio of the average $\mathrm{DO}^{14} \mathrm{C}$ release to the average respiration $\left({ }^{14} \mathrm{CO}_{2}\right.$ release $)$, each averaged for an entire month, does not equal the ratio of $D \mathrm{O}^{14} \mathrm{C}$ release to respiration calculated for each station, averaged over the entire month (Table 3). Although we cannot draw any conclusions about individual stations nor even months, overall it is clear that substantial amounts of $\mathrm{DO}^{14} \mathrm{C}$ were released during degradation of ${ }^{14} \mathrm{C}$-chitin

An experiment with coastal waters revealed an incorporation efficiency of $63 \%$ for chitin oligomers (percent respiration of $37 \%$ ). Assuming this percent

Table 2. Zooplankton numbers and molts in the Delaware Bay. The zooplankton were grouped according to length: small, $0.141 \pm 0.054( \pm \mathrm{SD}) \mathrm{mm}$; medium, $0.568 \pm 0.180 \mathrm{~mm}$; and large, $1.278 \pm 0.291 \mathrm{~mm}$. Zero distance is set at the mouth of the estuary; positive distances indicate stations up the estuary, and negative distance indicate stations in coastal waters

\begin{tabular}{|rrrrrr|}
\hline Cruise & $\begin{array}{c}\text { Distance } \\
(\mathrm{km})\end{array}$ & \multicolumn{5}{c}{ Zooplankton $\mathrm{l}^{-1}$} & ${\text { Molts } \mathrm{l}^{-1}}^{\text {Small }}$ & Medium & Large & \\
\hline $6 \mathrm{Jul}$ & 121 & 5633 & 533 & 250 & 0 \\
$6 \mathrm{Jul}$ & 82 & 8733 & 400 & 183 & 633 \\
$6 \mathrm{Jul}$ & 66 & 7857 & 571 & 143 & 0 \\
$5 \mathrm{Jul}$ & 38 & 46417 & 1967 & 633 & 1817 \\
$5 \mathrm{Jul}$ & 29 & 42714 & 5571 & 23000 & 0 \\
$5 \mathrm{Jul}$ & 9 & 18000 & 2417 & 600 & 0 \\
& & & & & \\
11 Oct & 100 & 3533 & 250 & 100 & 0 \\
10 Oct & 29 & 14467 & 283 & 167 & 850 \\
10 Oct & -11 & 11117 & 533 & 233 & 400 \\
10 Oct & -52 & 11550 & 2050 & 400 & 233 \\
& & & & & \\
\hline
\end{tabular}


Table 3. Summary of chitin hydrolysis ( $V_{\max }$ of MUF-diNAG hydrolysis) and degradation of ${ }^{14} \mathrm{C}$-chitin in the Delaware Estuary. Numbers are mean and $\mathrm{SD}$ of all samples in the Delaware Estuary (see Figs. 3 to 5)

\begin{tabular}{|c|c|c|c|c|c|}
\hline Date & $\begin{array}{c}\mathrm{DO}^{14} \mathrm{C} \\
\text { release } \\
\left(\mu g\left(\mathrm{l}^{-1} \mathrm{~d}^{-1}\right)\right.\end{array}$ & $\begin{array}{l}\text { Respiration } \\
\left(\mu \mathrm{g} \mathrm{Cl} \mathrm{l}^{-1} \mathrm{~d}^{-1}\right)\end{array}$ & $\% \mathrm{DO}^{14} \mathrm{C}^{\mathrm{d}}$ & $\begin{array}{l}\text { Hydrolysis } \\
\left(\mu g \mathrm{Cl}^{-1} \mathrm{~d}^{-1}\right)\end{array}$ & $\begin{array}{l}\text { Hydrolysis/ } \\
\text { degradation' }\end{array}$ \\
\hline $5-6 \mathrm{Jul}$ & $0.75 \pm 1.1$ & $0.7 \pm 0.4$ & $25 \pm 33$ & $9.24 \pm 6.4$ & 6.4 \\
\hline $6-9$ Sep & $2.45 \pm 2.5$ & $10.2 \pm 13.6$ & $52 \pm 39$ & $11.5 \pm 14.1$ & 0.9 \\
\hline $10-11 \mathrm{Oct}$ & $0.41 \pm 0.2$ & $0.4 \pm 0.2$ & $52 \pm 38$ & $2.35 \pm 3.16$ & 2.9 \\
\hline \multicolumn{6}{|c|}{$\begin{array}{l}\text { "Percent } D O C \text { release was calculated as: [DOC release/(DOC release }+ \text { Respi- } \\
\text { ration)] } \times 100 \text {. This percentage was calculated for each sample and then the } \\
\text { percentages were averaged for the entire month. Because of high variability } \\
\text { (see Figs. } 3 \text { to } 5 \text { ), the ratio of the averages does not equal the average of the } \\
\text { ratios }\end{array}$} \\
\hline
\end{tabular}

average of these 2 measures is sufficient to compare with estimates of chitin degradation. To determine how much bacterial production is supported by chitin, we applied the incorporation efficiency estimate to the respiration data (Table 4) in order to estimate the amount of chitin carbon incorporated into biomass. This parameter can be compared directly with bacterial biomass production.

The ratio of chitin hydrolysis to bacterial production ranged from 0.16 to 0.37 over the $3 \mathrm{mo}$, whereas the ratio of ${ }^{14} \mathrm{C}$-chitin incorporation into biomass to bacterial production was low (0.03 and 0.05) in July and

incorporation efficiency measured with 'soluble' chitin applies to particulate chitin, then of total chitin degraded over a $<24 \mathrm{~h}$ period, roughly $30 \%$ is released as DOC, another $30 \%$ is respired as $\mathrm{CO}_{2}$, and the remaining $40 \%$ is incorporated into bacterial biomass.

\section{Chitin hydrolysis and ${ }^{14} \mathrm{C}$-chitin degradation}

To compare MUF-diNAG hydrolysis (chitin hydrolysis) and ${ }^{14} \mathrm{C}$-chitin degradation directly, maximum rates of both were expressed as $\mu \mathrm{gC}^{-1} \mathrm{~d}^{-1}$. We added together respiration and solubilization rates since the sum of these processes should be closer to but still less than chitin hydrolysis as estimated by MUF-diNAG hydrolysis. Incorporation of chitin $\mathrm{C}$ into biomass was not included in the comparisons given in Fig. 6 because we have only 1 estimate of the incorporation efficiency. For chitin hydrolysis, we assume that $1 \mathrm{~mol}$ of MUF release implies the release of $1 \mathrm{~mol}$ of NAG.

Perhaps the most interesting observation is that ${ }^{14} \mathrm{C}$ chitin degradation was within an order of magnitude of chitinase activity, although MUF-diNAG hydrolysis was usually higher (Fig. 6). The difference between MUF-diNAG hydrolysis and ${ }^{14} \mathrm{C}$-chitin degradation was greatest in July (Fig. 6A) (different by a factor of 6 ; Table 3), whereas in September the 2 rates were nearly the same (Fig. 6B), which is clearly seen in the averages (Table 3). Both rates were highest in September (Fig. 6B) and lowest in October (Fig, 6C). Overall, the hydrolysis rate was 3 -fold greater than the sum of DO ${ }^{14} \mathrm{C}$ release and respiration. The difference is $1.7-$ fold if we account for incorporation of chitin carbon into bacterial biomass using the percent incorporation efficiency measured with soluble chitin oligomers

Bacterial production was estimated by both the thymidine and leucine techniques (Table 4 ), but the
October and high (0.55) in September (Table 4). The high ratio in September was due to fast rates of chitin degradation, not low bacterial production. With the possible exception of September, these data indicate

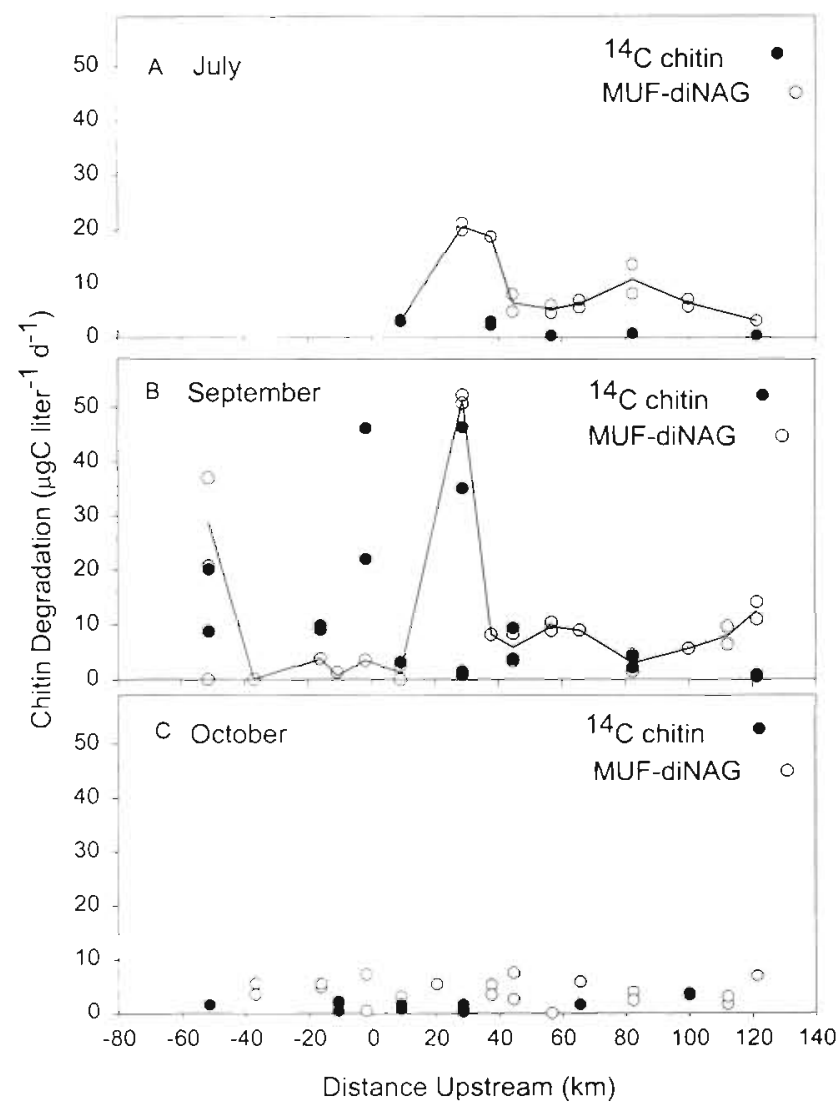

Fig. 6. Summary of chitin hydrolysis (MUF-diNAG hydrolysis) and chitin degradation $\left({ }^{14} \mathrm{C}\right.$-chitin) in equivalent units of $\mu \mathrm{g} \mathrm{C}$ $\mathrm{l}^{-1} \mathrm{~d}^{-1}$ during (A) July; (B) September; and (C) October. The ${ }^{14} \mathrm{C}$-chitin degradation estimates include both respiration and release of radioactivity as $\mathrm{DO}^{14} \mathrm{C}$ 
Table 4. Comparison of bacterial production (BP) with chitin hydrolysis (MUF-diNAG) and incorporation of chitin ${ }^{14} \mathrm{C}$ into biomass, as estimated from respiration rates and assuming $63 \%$ incorporation efficiency. Replication for hydrolysis and respiration are given in Fig. 6. Seven samples were taken for bacterial production measurements in July and 17 each month in September and October. SD includes variation in production over the entire transect through the estuary and into coastal waters

\begin{tabular}{|c|c|c|c|c|c|c|c|}
\hline & \multicolumn{5}{|c|}{ Bacterial production ( $\mu \mathrm{g} \mathrm{Cl}^{-1} \mathrm{~d}^{-1}$ ) } & \multirow[t]{2}{*}{ Hydrolysis/BPb } & \multirow[t]{2}{*}{ Incorporation/BP } \\
\hline & TdR & $\mathrm{SD}$ & Leu & SD & Mean $^{\circ}$ & & \\
\hline $5-6 \mathrm{Jul}$ & 47.1 & 36.3 & 21.7 & 26.6 & 34.4 & 0.27 & 0.02 \\
\hline $6-9$ Sep & 33.8 & 17.2 & 28.7 & 13.0 & 31.3 & 0.37 & 0.55 \\
\hline $10-11$ Oct & 14.1 & 4.8 & 14.8 & 7.0 & 14.5 & 0.16 & 0.05 \\
\hline \multicolumn{8}{|c|}{$\begin{array}{l}{ }^{a} \text { Mean of } \mathrm{TdR} \text { and Leu-based estimates } \\
{ }^{\mathrm{b}} \mathrm{Average} \text { bacterial production ( } \mathrm{TdR}+\mathrm{Leu} \text { ) was compared with the monthly averages for hydrolysis and incorporation of chitin } \\
{ }^{14} \mathrm{C} \text { into bacterial cells. Incorporation was estimated from respiration rates and assuming } 63 \% \text { efficiency. This efficiency } \\
\text { means that if } 100 \mathrm{~g} \text { of chitin carbon were taken up by bacteria, } 63 \mathrm{~g} \text { would be incorporated into biomass and } 37 \mathrm{~g} \text { respired as } \\
\mathrm{CO}_{2}\end{array}$} \\
\hline
\end{tabular}

that chitin supports little bacterial growth (order of $10 \%$ ) in Delaware waters.

We reach the same conclusions about the relative importance of chitin for supporting bacterial growth, i.e. low in 2 of the 3 mo, when other aspects of chitin degradation are compared with bacterial production. Ratios of chitin respiration to bacterial production are not substantially different $(0.02,0.33$ and 0.03 for July, September, and October, respectively) than the ratios given above for incorporation. The largest estimates of chitin degradation result from summing all 3 fates of chitin (DOC release, respiration, and incorporation), but this estimate also is relatively low for 2 mo and high for $1 \mathrm{mo}(0.08,0.96$, and 0.10 , respectively).

\section{DISCUSSION}

Chitin degradation and chitinolytic bacteria have been examined since ZoBell \& Rittenberg (1937), and its potential importance in the carbon cycle has been recognized at least since that study. Usually the contribution of chitin to carbon budgets is estimated from zooplankton abundance, but selected species of phytoplankton and heterotrophic protists are potentially even larger sources (Mulisch 1993). We know that bacteria require a fairly complex suite of enzymes to fully degrade chitin (e.g. Svitil et al. 1997) and many chitinase genes, including some from marine bacteria, have been sequenced (e.g. Svitil \& Kirchman 1998). What we do not know much about is the rate of chitin degradation and its ecological role in carbon and nitrogen cycling. It is commonly assumed that chitin must be degraded quickly because the water column and sediments are not filled with copepod exoskeletons (Harding 1973). Indeed, chitin may be degraded faster than cellulose (Hillman et al. 1989), and Boyer (1994) did find chitin degradation rates of 12 to $30 \% \mathrm{~d}^{-1}$ in an estuary. But reports of chitin preservation in fossils (e.g. Stankiewicz et al. 1997) suggest that chitin degradation may be more complex than commonly thought, and there are important issues about the fate of chitin that need to be examined in more detail.

One issue is the amount of bacterial growth supported by chitin degradation. Our results suggest that chitin does not support much bacterial production (order of $10 \%$ ). Given that the added chitin was $>250 \mu \mathrm{gl}^{-1}$, probably much higher than in situ concentrations, our estimates are probably higher than in situ rates. Montgomery et al. (1990) estimated chitin concentrations to be at most $20 \mu \mathrm{g}^{-1}$ in the Delaware Bay, a small fraction of total particulate carbon which is roughly $1 \mathrm{mg} \mathrm{C}^{-1}$ (Sharp et al. 1982), and quite small compared to our addition of $>250 \mu \mathrm{g} \mathrm{l}^{-1}$. Furthermore, we added purified chitin, whereas chitin in natural particles is associated with other macromolecules that may impede degradation, again suggesting our rates are maximum estimates. Another independent indication that chitin supports little bacterial growth directly is that even rates of chitin hydrolysis estimated from MUF-diNAG hydrolysis are low relative to bacterial production (average of 0.2 for all cruises; Table 4). Our estimates of bacterial production are similar to previous reports in the Delaware Estuary (Hoch \& Kirchman 1993), so it is the rate of chitin degradation that is low, not the production estimates

Our estimate of chitin turnover is $<1 \% \mathrm{~d}^{-1}$, similar to rates measured in some sediments from the disappearance of chitin (e.g. Hillman et al. 1989). In contrast, Boyer (1994) estimated chitin mineralization rates of $>10 \% \mathrm{~d}^{-1}$ in the York River. There are no obvious ecalogical reasons why our rates were so much lower than Boyer's, given the similarities between the Delaware and York River (Chesapeake) estuaries. Perhaps Boyer (1994) found much higher rates than our study because he added $100 \mathrm{mg} \mathrm{I}^{-1}$, several orders of magnitude 
greater than our addition. Also, his added tracer was probably not $100 \%$ chitin because his purification procedure, which consisted of only an ethanol wash, would not remove many compounds associated with chitin, especially covalently linked proteins (Schaefer et al. 1987). A positive aspect of the ${ }^{14} \mathrm{C}$-labeled material used by Boyer (1994) is that it is probably closer than our ${ }^{14} \mathrm{C}$-chitin to natural chitinous material encountered by estuarine microbes. In any case, we need more studies of marine microbes degrading complexes consisting of more than 1 organic compound (see Borch \& Kirchman 1999) in order to evaluate the effect of non-chitinous compounds on chitin hydrolysis.

Perhaps it is surprising that chitin supports 'only' on the order of $10 \%$ (or less) of bacterial production since so many marine organisms produce chitin, implying that much detrital chitin is available for degradation of bacteria. One explanation is that little of the chitin produced by various plankton groups becomes available to bacteria but rather is mineralized by other organisms, such as zooplankton feeding on diatoms and large particles. However, the gut passage time of zooplankton is on the order of an hour or less (Dam et al. 1988), making it unlikely that much chitin is degraded by zooplankton. Furthermore, when realistic estimates of chitin inputs are considered, it seems reasonable that chitin supports only about $10 \%$ of bacterial production. Chitin is 'only' $9 \%$ of copepod exoskeletons (Raymont et al. 1969), and at most about $15 \%$ of primary production could be as algal chitin; the latter estimate is based on Smucker \& Dawson (1986) data indicating that as much as $33 \%$ of the hot TCA-insoluble extract of ${ }^{14} \mathrm{C}$ in primary production assays ends up as chitin and the assumption that the hot TCA-insoluble fraction comprises $50 \%$ of total primary production (Morris 1981). Chitin still can be considered an important carbon source for estuarine bacteria because any single class of biochemicals is likely to be a small fraction of total organic material in an ecosystem, with the possible exception of protein which makes up as much as $60 \%$ of organisms. In fact, free amino acids and protein can support much bacterial growth in the Delaware Estuary in spring (Keil \& Kirchman 1993), but in July these compounds support only on the order of 10 to $25 \%$ of bacterial production, suggesting other compounds like chitin are more important during late summer and early fall.

Potentially, much bacterial growth is supported by the LMW byproducts released during chitin degradation, as our data and the estimates from Boyer (1994) indicate that release of DOM can be high, roughly equivalent to mineralization of chitin to $\mathrm{CO}_{2}$ and ammonium. The relatively high release of DOM is consistent with the observation that the rate of chitin hydrolysis (measured with MUF-diNAG) usually was greater than chitin mineralization (measured with ${ }^{14} \mathrm{C}$ chitin). We need to make several assumptions in order to make these estimates, but the 2 methods and their assumptions are independent of each other. Furthermore, the hydrolysis of a LMW analog may not be necessarily coupled to degradation of biopolymers in particulate material. So, it is rather remarkable that these 2 independent measures of chitin degradation are within an order of magnitude of each other. We are not aware of any analogous comparison between fluorogenic analog hydrolysis and polymer degradation.

Although potentially a large component of chitin degradation, DOM released during chitin hydrolysis does not appear to support much bacterial production as the ratio of released DOM to bacterial production is rather low (at most 0.08). Still, DOM release during the degradation of particulate detritus seems generally quite important, as illustrated by work in the Pacific. Cho \& Azam (1988) first observed that bacterial biomass production in the bathyopelagic zone was nearly equal to the sinking particle flux in the North Pacific Gyre and in California coastal waters, an observation supported by other work in the subarctic Pacific (Simon et al. 1992). Since nearly all bacteria are freeliving in the oceans (e.g. Alldredge et al. 1986) and since production at these depths must be supported by the sinking particle flux (ignoring possible advection of DOM to depth; Hansell et al. 1997), these data suggest that much POM is transferred to the dissolved state and then is utilized by apparently free-living bacterial assemblages (Cho \& Azam 1988). Smith et al. (1992) and our study show the release of DOM during POM degradation and thus demonstrate the transfer mechanism of particulate carbon to the dissolved pool. This transfer mechanism needs to be examined in greater detail.

Acknowledgements. We thank Matt Cottrell for his helpful comments on the manuscript and Ana Dittel for help in counting the diatoms and zooplankton. This work was supported by the DOE Ocean Margin Program and the NSF.

\section{LITERATURE CITED}

Alldredge AL, Cole JJ, Caron DA (1986) Production of heterotrophic bacteria inhabiting macroscopic organic aggregates (marine snow) from surface waters, Limnol Oceanogr 31:68-78

Bassler BL, Yu C, Lee YC, Roseman S (1991) Chitin utilization by marine bacteria: degradation and catabolism of chitin oligosaccharides by Vibrio furnissii. J Biol Chem 266: 24276-24286

Blackwell J, Parker KD, Rudall KM (1967) Chitin fibers of the diatom Thalassiosira fluviatilis and Cyclotella cryptica. J Mol Biol 28:383-385

Borch NH, Kirchman DL (1997) Concentration and composition of dissolved combined neutral sugars (polysaccha- 
rides) in sewater determined by HPLC-PAD. Mar Chem 57:85-95

Borch NH, Kirchman DL (1999) Protection of protein from bacterial degradation by submicron particles. Aquat Microb Ecol 16:265-272

Boyer J (1986) End products of anaerobic chitin degradation by salt marsh bacteria as substrates for dissimilatory sulfate reduction and methanogenesis. Appl Environ Microbiol 52:1415-1418

Boyer JN (1994) Aerobic and anaerobic degradation and mineralization of ${ }^{14} \mathrm{C}$-chitin by water column and sediment inocula of the York River Estuary, Virginia. Appl Environ Microbiol 60:174-179

Chin-Leo G, Kirchman DL (1988) Estimating bacterial production in marine waters from the simultaneous incorporation of thymidine and leucine. Appl Environ Microbiol 54:1934-1939

Cho BC, Azam F (1988) Major role of bacteria in biogeochemical fluxes in the ocean's interior. Nature 332:441-443

Chrétiennot-Dinet MJ, Giraud-Guille MM (1997) The chitinous nature of filaments ejected by Phaeocystis (Prymnesiophyceae). J Phycol 33:666-672

Crawford DL, Crawford RL (1976) Microbial degradation of lignocellulose: the lignin component. Appl Environ Microbiol 31:714-717

Dam HG, Peterson WT (1988) The effect of temperature on the gut clearance rate constant of planktonic copepods J Exp Mar Biol Ecol 123:1-14

Domard A, Cartier N (1989) Glucosamine oligomers: 1. Preparation and characterization. Int J Biol Macrornol 11 297-302

Gooday GW (1990) The ecology of chitin degradation. Adv Microb Ecol 11:387-430

Hansell DA, Bates NR, Carlson CA (1997) Predominance of vertical loss of carbon from surface waters of the equatorial Pacific Ocean. Nature 386:59-61

Harding GCH (1973) Decomposition of marine copepods. Limnol Oceanogr 18:670-673

Herwig RP, Pellerin NB, Irgens RL, Maki JS, Staley JT (1988) Chitinolytic bacteria and chitin mineralization in the marine waters and sediments along the Antarctic peninsula. FEMS Microb Ecol 53:101-112

Hillman K, Gooday GW, Prosser JI (1989) The mineralization of chitin in the sediments of the Ythan Estuary, Aberdeenshire, Scotland. Estuar Coast Shelf Sci 29:601-612

Hoch MP, Kirchman DL (1993) Seasonal and inter-annual variability in bacterial production and biomass in a temperate estuary. Mar Ecol Prog Ser 98:283-295

Keil RG, Kirchman DL (1993) Dissolved combined amino acids: chemical form and utilization by marine bacteria. Limnol Oceanogr 38:1256-1270

Lee S, Fuhrman JA. (1987) Relationships between biovolume and biomass of naturally derived marine bacterioplankton. Appl Environ Microbiol 53(6):1298-1303

McCarthy M, Pratum T, Hedges J, Benner R (1997) Chemical composition of dissolved organic nitrogen in the ocean. Nature 390:150-154

Montgomery MT, Kirchman DL (1993) Estimating degradation rates of chitin in aquatic samples. In: Kemp P, Sherr E, Sherr B, Cole JJ (eds) Current methods in aquatic microbial ecology. Lewis, Chelsea, MI, p 597-600

Montgomery MT, Welschmeyer NA, Kirchman DL (1990) A simple assay for chitin: application to sediment trap sam- ples from the subarctic Pacific. Mar Ecol Prog Ser 64: $301-308$

Morris I (1981) Photosynthetic products, physiological state, and phytoplankton growth. In: Platt $T$ (ed) Physiological bases of phytoplankton ecology. Department of Fisheries and Oceans, Ottawa, p 83-102

Mulisch M (1993) Chitin in protistan organisms: distribution, synthesis and deposition. Eur J Protistol 29:1-18

Newell SY (1993) Decomposition of shoots of a salt-marsh grass. In: Jones JG (ed) Advances in microbial ecology. Plenum Press, New York, p 301-326

Pakulski JD, Benner R (1992) An improved method for the hydrolysis and MBTH analysis of dissolved and particulate carbohydrates in seawater. Mar Chem 40:143-160

Raymont JEG, Srinivasagam RT, Raymont JKB (1969) Biochemical studies on marine zooplankton. VII. Observations on certain deep sea zooplankton. Int Rev Ges Hydrobiol 54:357-368

Roff JC, Kroetsch JT, Clarke AJ (1994) A radiochemical method for secondary production in planktonic crustacea based on rate of chitin synthesis. J Plankton Res 16: 961-976

Rosenstock B, Simon M (1993) Use of dissolved combined and free amino acids by planktonic bacteria in Lake Constance. Limnol Oceanogr 38:1521-1531

Rupley JA (1964) The hydrolysis of chitin by concentrated hydrochloric acid, and the preparation of low-molecularweight substrates for lysozyme. Biochim Biophy Acta 83: 245-255

Schaefer J, Kramer KJ, Garbow JR, Jacob GS, Stejskal EO, Hopkins TL, Speirs RD (1987) Aromatic cross-links in insect cuticle: detection by solid-state ${ }^{13} \mathrm{C}$ and ${ }^{15} \mathrm{~N}$ NMR. Science 235:1200-1204

Sharp JH, Culberson CH, Church TM (1982) The chemistry of the Delaware Estuary: general considerations. Limnol Oceanogr 27:1015-1028

Simon M, Welschmeyer NA, Kirchman DL (1992) Bacterial production and the sinking flux of particulate organic matter in the subarctic Pacific. Deep-Sea Res I 39:1997-2008

Smith DC, Simon M, Alldredge AL, Azam F (1992) Intense hydrolytic enzyme activity on marine aggregates and implications for rapid particle dissolution. Nature 359: $139-142$

Smucker RA, Dawson R (1986) Products of photosynthesis by marine phytoplankton: chitin in TCA 'protein' precipitates. J Exp Mar Biol Ecol 104:143-152

Stankiewicz BA, Briggs DEG, Evershed RP, Flannery MB, Wuttke M (1997) Preservation of chitin in 25-million-yearold fossils. Science 276:1541-1543

Svitil A, Kirchman DL (1.998) A chitin-binding domain in a marine bacterial chitinase and other microbial chitinases: implications for the evolution of 1,4- $\beta$-glycanases. Microbiology-UK 144:1299-1308

Svitil A, Ní Chadhain S, Moore JA, Kirchman DL (1997) Chitin degradation proteins produced by the marine bac terium Vibrio harveyi growing on different forms of chitin. Appl Environ Microbiol 63:408-413

Yoshikoshi K, Kô Y (1988) Structure and function of the peritrophic membranes of copepods. Nippon Suisan Gakkaishi 54:1077-1082

Zobell CE, Rittenberg SC (1937) The occurrence and characteristics of chitinoclastic bacteria in the sea. J Bacteriol 35 $275-287$

Submitted: August 31, 1998; Accepted: December 17, 1998 Proofs received from author(s): July 22, 1999 